equally highly. In fact the most common response on evaluations applauded the high quality of the presentations and commented that the information presented was new and professionally stimulating.

The project as a whole was equally successful. Several state associations that did not win grants decided to pay for an entire workshop themselves, thus further extending the service to the membership and impact of the grant. The grants paid $24 \%-84 \%$ of the total expenses of each workshop and an average of $55 \%$ of the expenses of all the workshops. The clearest expression of the value of this project comes from the final report of the New Mexico Library Association: "An ambitious undertaking...involving such high speaker costs... would not have been attempted without ALA financial assistance.... We hope that the Bibliographic Instruction Section will find justification in the evaluation reports from all the grant recipients to enable this grant program to be repeated."

\title{
Copyright: An ACRL resolution
}

\author{
Prepared by the ACRL Copyright Committee \\ Barbara Rystrom, Chair
}

\section{The guidelines referred to in the NYU settlement are too} restrictive.

$\mathbf{I}_{\mathrm{n}}$ In June 1983 the Association of American Publishers (AAP) sent a letter to college and university administrators urging them to adopt as their copyright compliance policy the agreement which New York University (NYU) accepted as part of the May 9, 1983, out-of-court settlement of the copyright infringement lawsuit brought against it by a group of publishers and coordinated by the AAP. ${ }^{1}$ Out-ofcourt settlements in lawsuits are not imposed by the courts and do not set legal precedents; therefore, such settlements are not necessarily appropriate models for entities not a party to the settlement.

The NYU policy states that faculty can expect the University to defend and indemnify them in the event of a claim of copyright infringement only if the faculty member has followed the guidelines incorporated in the policy, gotten permission from

${ }^{1}$ Chronicle of Higher Education, April 20, 1983, pp.1, 22. the copyright owner, or cleared the copying with the General Counsel of the University. The guidelines incorporated in the policy are familiar to copyright observers, because they are from the Agreement on Guidelines for Classroom Copying in Not-for-Profit Educational Institutions with Respect to Books and Periodicals (hereafter referred to as the Classroom Guidelines). Designed to clarify the principle of fair use as it applies to copying for classroom instruction, and to provide "greater certainty and protection for teachers," the Classroom Guidelines were negotiated by primary and secondary school educators with authors and publishers, and were incorporated into the House Report on the copyright law. ${ }^{2}$ The American Associa-

${ }^{2}$ U.S. House of Representatives. Committee on the Judiciary. Report on Copyright Law Revision, H.R. 94-1476, September 3, 1976, pp.68-70, with corrections in the Congressional Record, September 21, 1976, pp. H10727-28. 
tion of University Professors and the Association of American Law Schools were not parties to the agreement, which they felt was too restrictive in the college and university context. The Association of Research Libraries has described the Classroom Guidelines as "unsuitable in the context of postsecondary education," and the American Library Association has stated that the Classroom Guidelines "normally would not be realistic in the University setting."

Though the Classroom Guidelines clearly state the purpose is "to state the minimum and not the maximum standards of educational fair use," experience shows that such guidelines are often referred to as if they provided outer limits; for example, the NYU policy says that permission is required for copying "not permitted under the (Classroom) Guidelines." And those Guidelines are truly limiting. Among other details, the Cumulative Effect section indicates that a given item can be copied "for only one course in the school in which the copies are made," and that "not more than one short poem, article, story, essay or two excerpts may be copied from the same author, nor more than three from the same collective work or periodical volume during one class term." The Brevity section limits copying of poetry to "a complete poem if less than 250 words" or "from a longer poem, an excerpt of not more than 250 words," and copying of prose to less than 2,500 words. It is clear that these stipulations are unworkable in a postsecondary setting.

The ACRL Copyright Committee shares the opinion that the Classroom Guidelines are not appropriate for colleges and universities and that, therefore, the NYU policy, which incorporates them, is not an appropriate model. The ALA Model Policy Concerning College and University Photocopying for Classroom, Research and $\mathrm{Li}$ brary Reserve Use, reprinted in C\&RL News, April 1982, pp. 127-31, offers a much more pertinent interpretation of fair use. In addition, several institutions have devised copyright compliance policies which are appropriate for colleges and universities. Therefore, at its Midwinter 1984 meetings, the Committee drafted the following resolution, which was adopted by the ACRL Board at its meeting at the end of the conference.

The ACRL Copyright Committee would welcome comment on this and any other copyright related issue, and urges college and university librarians to keep it informed about local developments and problems in copyright at their institutions. Please contact the chair at the University of Georgia Libraries, Athens, GA 30602; (404) 542-3274.

${ }^{3}$ Association of Research Libraries, "Reproduction of Copyrighted Materials for Classroom Use: A Briefing Paper for Teaching Faculty and Administrators," July 1983, available from ARL; "Model Policy Concerning College and University Photocopying for Classroom, Research and Library Reserve Use," C\&RL News, April 1982, pp.127, 129.

\section{The resolution}

Whereas, the 1982 lawsuit settlement between New York University (NYU) and nine publishers calls for NYU to adopt campus wide guidelines on photocopying instructional materials which duplicate almost verbatim the copying standards set forth in the Agreement on Guidelines for Classroom Copying in Not for Profit Educational Institutions with Respect to Books and Periodicals;

Whereas, the Agreement on Guidelines for Classroom Copying, developed by primary and secondary school educators and publishers, was criticized by the American Association of University Professors and the American Association of Law Schools as too restrictive for classroom application at the university level;

Whereas, the Association of American Publishers has openty and aggressively encouraged the NYU guidelines be adopted by all colleges and universities;

Whereas, the American Library Association's Model Policy Concerning College and University Photocopying for Classroom, Research and $\mathrm{Li}$ brary Reserve Use, which is more appropriate to academic institutions and their libraries, offers a legitimate and less restrictive interpretation of Fair Use than the NYU guidelines;

Whereas, other academic institutions have adopted acceptable and legitimate copyright guidelines other than those resulting from the NYU settlement. Now, therefore be it resolved,

That colleges and universities and their libraries should continue to interpret the Copyright Act in a manner that is in the spirit of the law and consistent with the rights and needs of both copyright proprietors and the academic community, and need not conform to the guidelines as set forth in the NYU settlement.

\section{Copyright bibliography}

Mary Lee Sweat, university librarian at Loyola University, New Orleans, has compiled a bibliography of current (1982-present) articles on copyright for the ACRL Copyright Committee. The articles are drawn from the results of an online search of four databases: ERIC, LISA, Legal Resources Index, and the Microcomputer Index.

Persons interested in copyright may obtain a copy of the 8-page bibliography by sending an SASE to Mary Lee Sweat, University Librarian, Loyola University, 6363 St. Charles Street, New Orleans, LA 70118.

She would also appreciate receiving a copy of any institutional copyright policies or guidelines which your library employs. 


\section{A fortunate choice.}

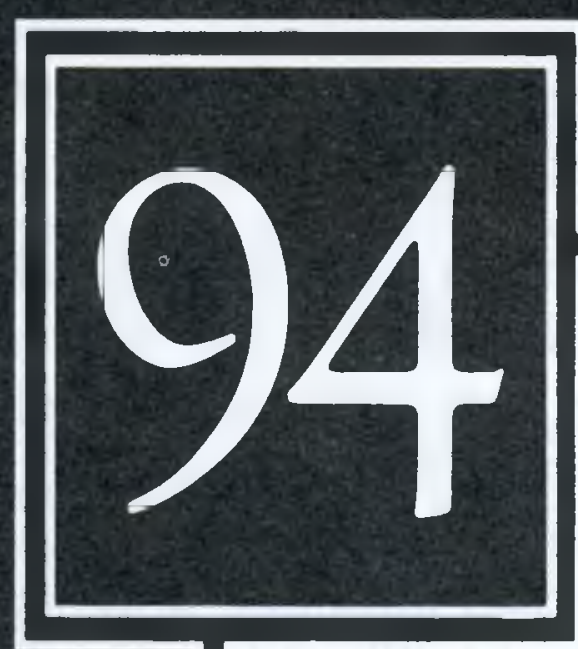

of the Fortune $100 \mathrm{com}$ -

panies choose ABI/INFORM $^{\circledR}$ as their business database. Simply because ABI/INFORM helps them solve business and management problems. Enhance strategic planning. Speak with authority. And this valuable information resource costs no more today than it did in 1982. ABI/INFORM summarizes the major articles in more than 600 business publications worldwide. And Data Courier can provide you with the full text of most articles through an inexpensive article delivery service. It's easy to see why the largest and most successful corporations choose ABI/INFORM. Fortunately, your organization can make the same choice. Call 800/626-2823 to find out more.

Data Courier Inc 